\title{
ANALISIS PEMBELAJARAN ONLINE TERHADAP KETERAMPILAN SOSIAL SISWA SEKOLAH DASAR PADA MASA PANDEMIC COVID-19
}

\author{
Dina Nur Amala ${ }^{1}$, Fajar Setiawan ${ }^{2}$, Meirza Nanda Faradita ${ }^{3}$ \\ 1,2,3 Program Studi PGSD, Universitas Muhammadiyah Surabaya \\ Correspondence Email: dina.nur.amala-2019@fkip.um-surabaya.ac.id
}

Received: June 3, 2020 Revised: June 8, 2020 Accepted: June 11, 2020

\begin{abstract}
ABSTRAK
Penelitian ini berawal dari munculnya sebuah virus Covid-19 yang menyebabkan pandemi global sehingga mengharuskan pembelajaran di sekolah menjadi pembelajaran online. Dalam pembelajaran online sangatlah berbeda dengan pembelajaran saat disekolah, terutama pada keterampilan sosial pada siswa, siswa cenderung belajar melalui alat komunikasi tanpa bertemu langsung dengan kondisi lingkungan yang nyata, hal itu menyebabkan keterampilan sosial siswa menjadi berbeda. Tujuan dari penelitian ini adalah untuk mengetahui pelaksanaan pembelajaran online terhadap keterampilan sosial siswa sekolah dasar pada masa pandemic Covid-19. Penelitian ini menggunakan lima indikator keterampilan sosial dari Caldarella dan Merrel yaitu hubungan dengan teman sebaya, manajemen diri, kemampuan akademis, kepatuhan, dan perilaku assertif. Penelitian kualitatif ini dilakukan di SD Muhammadiyah 8 Surabaya dengan sumber data primer yang digunakan adalah siswa kelas II C di SD Muhammadiyah 8 Surabaya yang berjumlah 27 siswa. Teknik pengumpulan data menggunakan teknik angket (kuesioner) melalui google forms pada data yang telah didapatkan selama proses belajar mengajar secara online berlangsung. Hasil penelitian menunjukkan pada indikator hubungan dengan teman sebaya sebanyak 45,55\%, manajemen diri sebanyak $82,96 \%$, kemampuan akademis $79,62 \%$, kepatuhan sebanyak $81,72 \%$, perilaku assertif sebanyak $55,55 \%$, maka dapat disimpulkan sebanyak 68,96 \% siswa sudah memenuhi lima indikator keterampilan sosial siswa saat pembelajaran online.
\end{abstract}

Kata Kunci: Pembelajaran Online, Keterampilan Sosial, Covid-19

Abstract: This research originated from the emergence of a Covid-19 virus which caused a global pandemic, which requires learning in schools to become online learning. In online learning it is very different from learning at school, especially in social skills in students, students tend to learn through communication tools without meeting directly with real environmental conditions, this causes students' social skills to be different. The purpose of this study was to determine the implementation of online learning on the social skills of elementary school students during the Covid-19 pandemic. This study uses five indicators of social skills from Caldarella and Merrel, namely peer relationships, self-management, academic ability, obedience, and assertive behavior. This qualitative research was conducted at SD Muhammadiyah 8 Surabaya with the primary data source used were students of class II C at SD Muhammadiyah 8 Surabaya, totaling 27 students. The data collection technique uses a questionnaire technique (questionnaire) through google forms on the data that has been obtained during the online teaching and learning process. The results showed that the indicators of relationships with peers were $45.55 \%$, self-management was $82.96 \%$, academic ability was $79.62 \%$, obedience was $81.72 \%$, assertive behavior was $55.55 \%$, it can be concluded as much as $68,96 \%$ of students have met the five indicators of student social skills when learning online.

Keywords: Online Learning, Social Skills, Covid-19 


\section{PENDAHULUAN}

Pada zaman sekarang ini, dunia kesehatan sedang mengalami kondisi mencekam, dimana munculnya sebuah virus penyakit yang hampir sudah tersebar di seluruh belahan dunia, virus tersebut dinamakan Coronavirus Disease (Covid-19) (Darmalaksana, dkk., 2020). Virus ini berasal dari kota Wuhan, Tiongkok, Cina dan muncul pada akhir Desember tahun 2019. Tanda dan gejala umum infeksi virus Covid-19 ini yaitu gejala gangguan pernapasan akut, seperti demam, batuk, dan sesak napasserta masa inkubasi rata-rata 5-6 hari dengan masa inkubasi terpanjang 14 hari (Astini, 2020). Penyebaran virus ini cepat sekali menyebar luas ke seluruh penjuru masyarakat di China, sehingga membuat pemerintah China merasa kewalahan dalam menangani kasus corona virus di negaranya dan tidak hanya itu, virus ini sudah menyebar ke berbagai Negara dan mengakibatkan pandemic global yang berlangsung saat ini dikarenakan terbawa oleh manusia ke manusia lain. Menurut data WHO sejak tanggal 1 Maret 2020 tercatat sudah dipastikan terdapat 65 negara yang sudah telah tertular virus ini (Yuliana, 2020). Dari 65 negara tersebut, diantaranya Negara Indonesia.

Menurut artikel Kompas.com, salah satu usaha untuk mencegah penularan virus ini dengan menerapkan social distancing (pembatasan jarak sosial) yang dirancang untuk mengurangi interaksi antara orang-orang dalam komunitas yang lebih luas, mulai dari penutupan bandara hingga pemberlakuan pembatasan terhadap pergerakan warganya. Langkah ini tidak berarti bahwa seseorang harus memutuskan hubungan dan komunikasi dengan orang yang dicintai atau dari keluarganya, banyak sekali alternatif yang bisa dilakukan selain bertemu langsung, bisa melalui panggilan video, Whatsapp video, dan aplikasi video yang lainnya. "Saat ini, berkat teknologi yang telah maju, kita dapat tetap terhubung dengan berbagai cara tanpa benar-benar berada dalam ruangan yang sama dengan orang- orang lain secara fisik," kata ahli epidemiologi WHO Maria Van Kerkhove pada 20 Maret lalu (Kompas.com).

Selain penerapan social distancing, banyak juga sektor-sektor yang mengalami kerugian diakibatkan dari virus Covid-19 ini, mulai dari sektor perdagangan yang sepi pengunjung dan diharuskan dirumah saja, hingga sektor pendidikan yang tidak memperbolehkan adanya aktivitas belajar mengajar di sekolah sesuai dengan surat keputusan pemerintah surat edaran nomor 4 tahun 2020 tentang pelaksaaan kebijakan pendidikan dalam masa darurat penyebaran coronavirus disesase (Covid-19) memutuskan bahwa proses belajar dilakukan di rumah dimana siswa belajar secara daring dan tidak berangkat ke sekolah (https://www.kemdikbud.go.id). 
Belajar adalah merupakan proses perubahan tingkah laku seseorang dari yang tidak tahu menjadi. Belajar dapat dilakukan di mana saja, tidak hanya di kelas, dengan adanya fasilitator membuat siswa menjadi terarah untuk mencapai tujuan pembelajaran. fasilitator disini adalah guru (Faradita, 2019). Jika dikaitkan dengan situasi ini menuntut para guru dan siswa belajar melalui online. Pembelajaran online menjadi alternatif pembelajaran jarak jauh untuk menunjang proses belajar mengajar pada masa Pandemic Covid-19 sehingga dapat memutus penyebaran virus Covid-19.

Pembelajaran online adalah salah satu pembelajaran jarak jauh dengan menggunakan fasilitas internet sehingga dapat saling berkomunikasi secara online, Menurut Herayanti dkk (2017) menyimpulkan bahwa "Pembelajaran online diartikan sebagai jenis pembelajaran yang memungkinkan tersampainya bahan ajar ke siswa dengan menggunakan media internet atau media dalam jaringan komputer lainnya”. Dalam situasi seperti saat ini, diharapkan pembelajaran online dapat membantu guru dalam melaksanakan kurikulum pendidikan.

Kurikulum pendidikan dirancang untuk mengembangkan beberapa keterampilan dalam diri siswa. Forgarty (dalam Fitriani, dkk, 2017) menyatakan keterampilan yang diintegrasikan dalam pembelajaran adalah keterampilan belajar, yang terdiri dari keterampilan sosial, keterampilan berpikir, dan keterampilan mengorganisir. Untuk mencapai tujuan pembelajaran tersebut, guru harus lebih kreatif dalam mengembangkan kurikulum untuk menciptakan pembelajaran, yang menghasilkan nilai, sikap dan keterampilan sosial yang tergambar sebagai hasil belajar yang ditentukan oleh masing-masing instansi pendidikan. Menurut Setiawan (2018), keterampilan dalam diri siswa dalam wujud nyata bermasyarakat, setiap individu dituntut untuk memiliki keterampilan dalam melakukan interkasi, baik dengan keluarga, saudara, teman sebaya (peer group) dan lingkungan sosialnya.

Menurut Fitriani (2017), keterampilan sosial adalah kemampuan individu dalam menjalin komunikasi dan interaksi dengan orang lain diantaranya kemampuan untuk bekerjasama, berbagi, berpartisipasi, berteman, membantu orang lain, mengikuti aturan- aturan menerima perbedaan, mendengarkan dan menghargai orang lain serta menghargai diri sendiri dan bersikap sopan santun. Keterampilan sosial merupakan keterampilan yang harus dimiliki oleh setiap individu karena manusia adalah makhluk sosial yang selalu berinteraksi dengan lingkungan sosialnya dan masih membutuhkan orang lain, kurangnya keterampilan sosial siswa akan berdampak pada rendahnya prestasi akademik siswa tersebut dikarenakan munculnya rasa kesepian dan menurunnya kepercayaan diri siswa (Muijs dalam Minarni, 2013)

Dalam pembelajaran online sangatlah berbeda dengan pembelajaran pada umumnya. Saat pembelajaran dikelas, siswa dapat berinteraksi sosial dengan teman sekelasnya dan bekerja 
sama saat belajar kelompok. Saat pembelajaran online, siswa hanya berinteraksi dengan temannya melalui pembelajaran tatap muka virtual yaitu panggilan video dan aplikasi percakapan melalui whatsapp. Oleh karena itu, akibat dari pandemic Covid-19 ini menyebabkan kemampuan ketrampilan sosial pada anak sekolah dasar menjadi berkurang dikarenakan interaksi melalui online masih belum setara dengan interaksi secara langsung.

Aspek keterampilan sosial menurut menurut Caldarella dan Merrel (dalam Purnama, 2017) terdapat lima untuk anak-anak dan remaja, meliputi :

a. Hubungan dengan teman sebaya (Peer relationship skills), yaitu perilaku yang menunjukkan hubungan yang positif dengan teman sebaya yang meliputi perilaku yang disukai, empati, partisipasi sosial, sociability leadership, menawarkan bantuan ketika dibutuhkan, berpartisipasi dalam diskusi, berbicara dengan teman sebaya, hubungan dengan teman sebaya maupun hubungan dengan orang lain.

b. Manajemen diri (Self management skills), yaitu kemampuan individu untuk mengatur dirinya sendiri yang meliputi pengendalian diri, kemandirian sosial, kompetensi sosial, tanggung jawab sosial, melakukan kompromi secara tepat dengan orang lain, berkomunikasi dan bekerja sama dengan orang lain.

c. Kemampuan akademis (Academic skills), yaitu kemampuan individu yang mendukung prestasi belajar yang meliputi penyesuaian diri terhadap lingkungan sekolah, menghormati aturan sekolah, memahami materi, mendengarkan dan melaksanakan petunjuk dari guru, bertanya atau meminta bantuan secara tepat, orientasi tugas dan tanggung jawab akademik.

d. Kepatuhan (Complience skills), yaitu kemampuan individu untuk memenuhi permintaan orang lain yang meliputi kerjasama, hubungan dengan teman/ orang lain, penyesuaian dengan orang lain., menyelesaikan tugas dengan tepat waktu, mengikuti instruksi atau petunjuk, mematuhi dan mentaati peraturan.

e. Perilaku assertif (Assertion skills), yaitu perilaku yang didominasi oleh kemampuankemampuan yang membuat individu dapat menampilkan perilaku yang tepat dalam situasi yang diharapkan yang meliputi mengawali percakapan, ketegasan, inisiasi sosial, penggerak sosial, mengajukan pertanyaan, berani.

Indikator keterampilan sosial dalam penelitian ini akan diukur dengan menggunakan 5 (lima) aspek keterampilan sosial dari Caldarella dan Merrel yaitu hubungan dengan teman sebaya, manajemen diri, kemampuan akademis, kepatuhan, dan perilaku assertive. Berdasarkan kondisi yang terjadi selama pandemi Covid-19 serta kajian dari beberapa teori di atas maka tujuan penulisan artikel ini adalah untuk mengetahui pelaksanaan pembelajaran online terhadap keterampilan sosial siswa sekolah dasar pada masa pandemic Covid-19. 


\section{METODE PENELITIAN}

Metode penelitian yang akan dilakukan peneliti menggunakan metode kualitatif. Menurut Nazir (1988) penelitian kualitatif adalah penelitian yang digunakan untuk memahami kejadian tentang apa yang dialami oleh subjek penelitian misalnya perilaku, persepsi, motivasi, tindakan dalam bentuk kata-kata dan bahasa pada suatu konteks khusus yang alamiah. Metode penelitian kualitatif mendapatkan data berupa deskripsi pendapat dari responden ataupun hasil catatan lapangan berdasarkan dari pengamatan selama proses pembelajaran online dari rumah. Lokasi penelitian ini adalah Sekolah Dasar Muhammadiyah 8 Surabaya. Adapun sumber data primer yang digunakan adalah siswa kelas II C di SD Muhammadiyah 8 Surabaya yang berjumlah 27 siswa, adapun sumber data sekundernya adalah sumber-sumber kepustakaan, seperti jurnal-jurnal ilmiah, internet, dan juga sumber- sumber lain yang masih relevan dengan penelitian ini.

Teknik pengumpulan data menggunakan teknik angket (kuisioner) melalui google forms. Menurut Bungin (dalam Suhandani, 2014), angket merupakan daftar pertanyaan yang disusun secara sistematis dan diberikan kepada orang lain (responden) dengan maksud agar orang yang diberi tersebut bersedia memberikan respon sesuai dengan permintaan peneliti. Selama proses pengumpulan data untuk mengumpulkan informasi dari kuesioner/angket melalui google forms pada data yang telah didapatkan selama proses belajar mengajar secara online berlangsung. Adapun pedoman kisi-kisi angket penelitiannya sebagai berikut

Tabel 1. Pedoman kisi-kisi Angket Keterampilan Sosial Siswa

\begin{tabular}{|l|l|l|c|}
\hline $\begin{array}{l}\text { N } \\
\text { O. }\end{array}$ & $\begin{array}{l}\text { INDIKATOR KETERAMPILAN } \\
\text { SOSIAL YANG DIAMATI }\end{array}$ & \multicolumn{1}{|c|}{ SUB INDIKATOR } & NO. ITEM \\
\hline \multirow{2}{*}{2.} & Hubungan dengan teman sebaya & $\begin{array}{l}\text { Menunjukkan sikap berdiskusi } \\
\text { dengan teman sebaya saat } \\
\text { pembelajaran online }\end{array}$ & 5 \\
\cline { 3 - 4 } & Manajemen diri & $\begin{array}{l}\text { Menunjukkan sikap membantu } \\
\text { teman sebaya saat pembelajaran } \\
\text { online }\end{array}$ & 7 \\
\hline \multirow{2}{*}{3.} & Kemampuan akademis & $\begin{array}{l}\text { Menunjukkan sikap berkomunikasi } \\
\text { dengan orang lain saat pembelajaran } \\
\text { online }\end{array}$ & 3 \\
\hline & $\begin{array}{l}\text { Menunjukkan sikap mendengarkan } \\
\text { penjelasan guru saat pembelajaran } \\
\text { online }\end{array}$ & \multicolumn{2}{|c|}{1} \\
\cline { 3 - 5 } & $\begin{array}{l}\text { Menunjukkan sikap memahami } \\
\text { materi saat pembelajaran online }\end{array}$ & \multicolumn{2}{|c|}{4} \\
\hline
\end{tabular}




\begin{tabular}{|l|l|l|c|}
\hline \multirow{2}{*}{$\begin{array}{l}\mathrm{N} \\
\mathrm{O} .\end{array}$} & $\begin{array}{l}\text { INDIKATOR KETERAMPILAN } \\
\text { SOSIAL YANG DIAMATI }\end{array}$ & \multicolumn{1}{|c|}{ SUB INDIKATOR } & NO. ITEM \\
\hline \multirow{2}{*}{4.} & \multirow{2}{*}{ Kepatuhan } & $\begin{array}{l}\text { Menunjukkan sikap mengumpulkan } \\
\text { tugas dengan tepat waktu }\end{array}$ & 8 \\
\cline { 3 - 5 } & & $\begin{array}{l}\text { Menunjukkan sikap mematuhi aturan } \\
\text { saat pembelajaran online }\end{array}$ & \multicolumn{2}{|c|}{9} \\
\cline { 3 - 5 } & $\begin{array}{l}\text { Menunjukkan sikap mematuhi aturan } \\
\text { saat pembelajaran online }\end{array}$ & 10 \\
\hline 5. & Perilaku assertif & $\begin{array}{l}\text { Menunjukkan sikap berani } \\
\text { mengajukan pertanyaan saat } \\
\text { pembelajaran online }\end{array}$ & 2 \\
\cline { 3 - 5 } & $\begin{array}{l}\text { Menunjukkan sikap berani } \\
\text { berinteraksi saat pembelajaran online }\end{array}$ & 6 \\
\hline
\end{tabular}

Data yang diperoleh dari kuesioner (angket) melalui google forms maka selanjutnya akan dilakukan pengolahan data dan analisis data. Teknik analisis data dalam penelitian ini menurut Miles dan Huberman (dalam Agusta, 2003) terdiri dari 3, yaitu meliputi: 1) Reduksi data adalah proses analisis yang dilakukan untuk memilih, mengarahkan dan mengorganisir data dengan cara sedemikian rupa sehingga kesimpulan akhir dapat diambil. Reduksi data dapat dengan cara seleksi ketat atas data, ringkasan atau uraian singkat, dan menggolokannya dalam pola yang lebih luas, 2) Penyajian data adalah sekumpulan informasi yang disusun sehingga dapat mempermudah memberikan kemungkinan adanya penarikan kesimpulan, 3) Penarikan kesimpulan adalah proses upaya untuk mencari makna, arti dan penjelasan dari data yang dikumpulkan.

Hasil penilaian terhadap seluruh aspek di ukur dengan menggunakan skala likert. Skala likert merupakan sejumlah pernyataan positif atau negative mengenai suatu obyek sikap (Ernawati, 2017). Dalam penelitian ini jawaban butir instrumen diklasifikasikan menjadi lima pilihan. Setiap pertanyaan yang diukur diberikan skala skor 1-5, yaitu 5 (selalu), 4 (sering), 3 (kadang-kadang), 2 (tidak pernah), 1 (tidak pernah sama sekali). Langkah selanjutnya adalah menilai hasil skor dengan menggunakan rumus:

Hasil skor $=\sum$ (frekuensi kemunculan jawaban $\mathrm{x}$ nilai skala)

(Maryuliana, dkk, 2016)

Setelah diperoleh hasil skor, selanjutnya rumus persentase hasil dapat dihitung dengan rumus sebagai berikut:

$$
\text { Hasil akhir }(\%)=\frac{\text { Hasil skor }}{\text { Nilai skala terbesar } \mathrm{x} \text { jumlah responden }} \times 100 \%
$$

(Maryuliana, dkk, 2016) 


\section{HASIL DAN PEMBAHASAN}

Berdasarkan hasil yang diperoleh dari kuesioner keterampilan sosial saat pembelajaran online melalui google forms yang berdasarkan 5 indikator keterampilan sosial, yaitu: hubungan teman sebaya, manajemen diri, kemampuan akademis, kepatuhan, dan perilaku assertive sebanyak 68,96\% atau 18 siswa dari 27 siswa telah memenuhi 5 indikator tersebut. Sebanyak $31,04 \%$ siswa belum memenuhi seluruh indikator. Adapun rincian prosentase pencapaian masing-masing indikator yaitu sebagai berikut:

1. Siswa yang memenuhi indikator hubungan dengan teman sebaya sebanyak $45,55 \%$. Adapun sub indikator menunjukkan siswa berdiskusi dengan teman sebaya saat pembelajaran online sebanyak $47,40 \%$ dan menunjukkan sikap membantu teman sebaya saat pembelajaran online sebanyak 43,70\%. Dalam hal ini siswa masih kurang dalam hubungan dengan teman sebaya karena pada tahap ini siswa masih membutuhkan adaptasi dengan teman baru. Berikut hasil respon keterampilan sosial siswa pada indikator hubungan dengan teman sebaya (pernyataan no 5 dan 7) dalam diagram berikut ini:
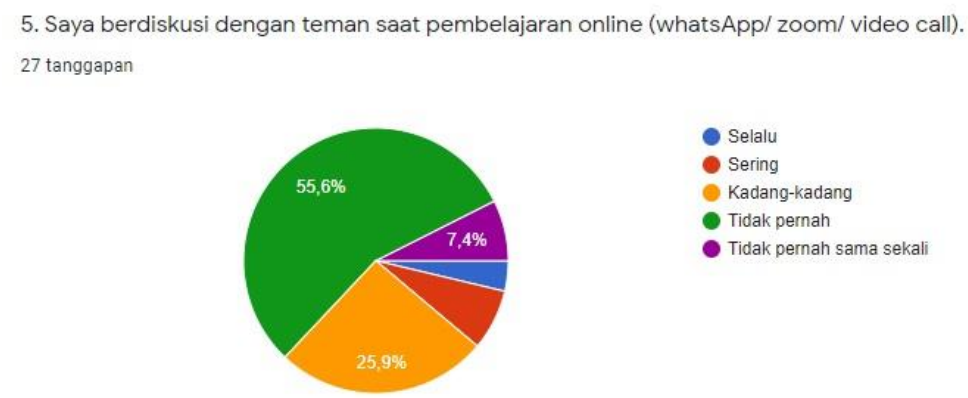

Gambar 1. Hasil respon pernyataan nomor 5

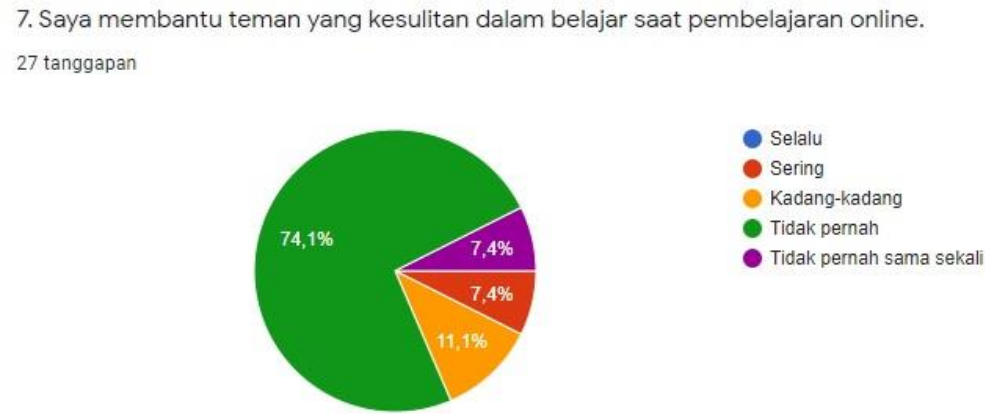

Gambar 2. Hasil respon pernyataan nomor 7

2. Siswa yang memenuhi indikator manajemen diri sebanyak $82,96 \%$ dengan sub indikator berkomunikasi dengan orang lain saat pembelajaran. Dalam hal ini siswa sudah mampu untuk berkomunikasi dengan guru dengan bantuan aplikasi online whatsapp, zoom meeting, dan aplikasi online lainnya. Berikut hasil respon keterampilan sosial siswa pada indikator manajemen diri (pernyataan no 3) dalam diagram berikut ini: 
3. Pembelajaran online (whatsApp/ zoom/ video call) selama ini saya bisa berkomunikasi dengan guru.

27 tanggapan

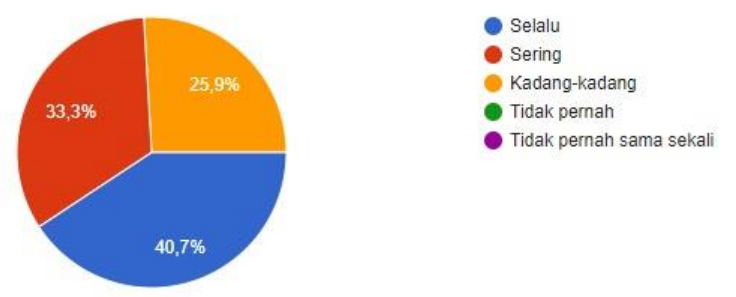

Gambar 3. Hasil respon pernyataan nomor 3

3. Sebanyak $79,62 \%$ siswa memenuhi indikator kemampuan akademis saat pembelajaran online dengan sub indikator menunjukkan sikap mendengarkan penjelasan guru saat pembelajaran online sebanyak $83,70 \%$ dan menunjukkan sikap memahami materi saat pembelajaran online sebanyak 75,55\%. Berikut hasil respon keterampilan sosial siswa pada indikator kemampuan akademis (pernyataan no 1 dan 4) dalam diagram berikut ini:
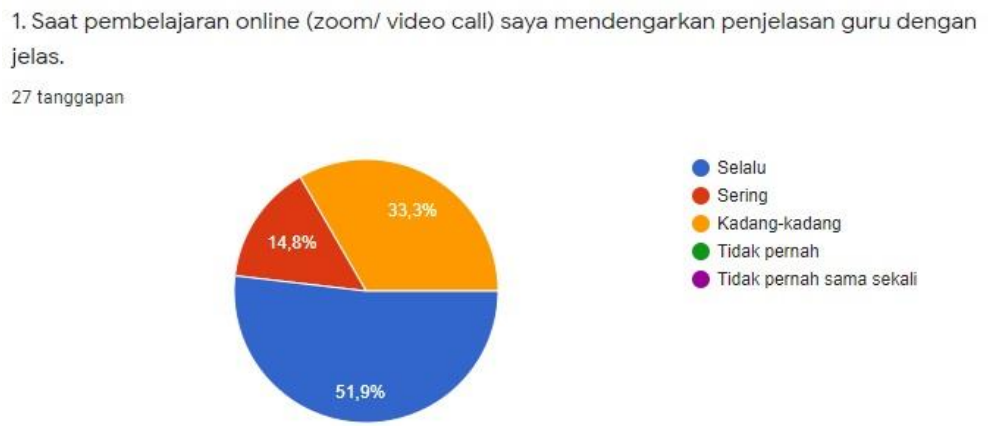

Sering

Kadang-kadang

- Tidak pernah

- Tidak pernah sama sekali

Gambar 4. Hasil respon pernyataan nomor 1

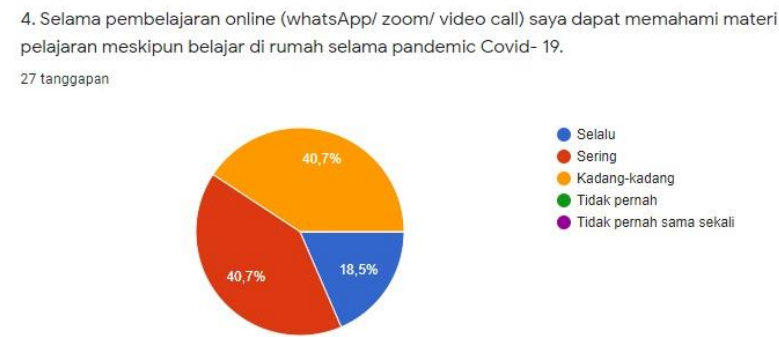

Gambar 5. Hasil respon pernyataan nomor 4

4. Siswa yang memenuhi indikator kepatuhan sebanyak $81,72 \%$ dengan sub indikator menunjukkan sikap mengumpulkan tugas dengan tepat waktu sebanyak $74,81 \%$ dan menunjukkan sikap mematuhi aturan saat pembelajaran online sebanyak 85,92\% serta menunjukkan sikap mematuhi aturan ketika pembelajaran tatap muka virtual sebanyak $84,44 \%$. Berikut hasil respon keterampilan sosial siswa pada indikator kemampuan akademis (pernyataan no 8, 9, dan 10) dalam diagram berikut ini: 
8. Saya mengumpulkan tugas dengan tepat waktu.

27 tanggapan

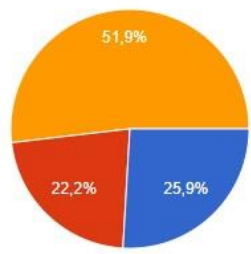

- Selalu

Kadang-kadang

- Tidak pernah

- Tidak pernah sama sekali

Gambar 6. Hasil respon pernyataan nomor 8

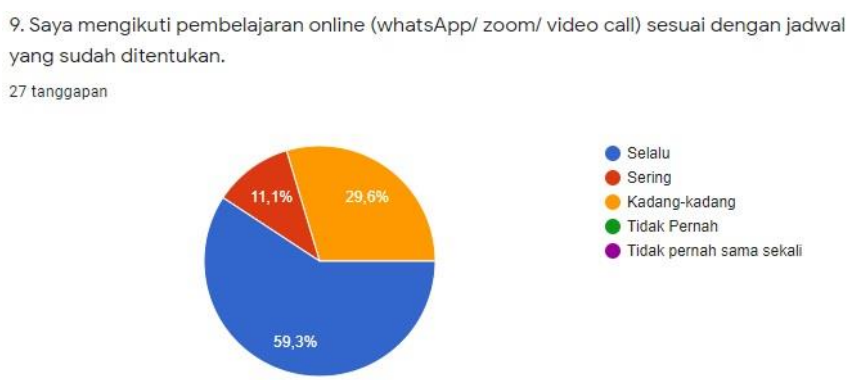

Gambar 7. Hasil respon pernyataan nomor 9

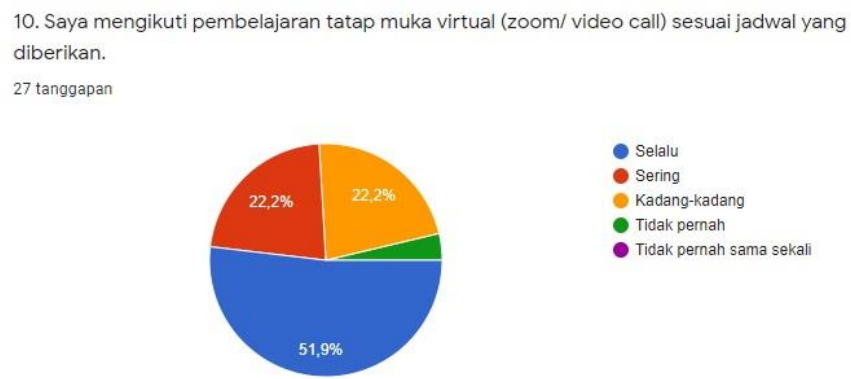

Gambar 8. Hasil respon pernyataan nomor 10

5. Siswa yang memenuhi indikator perilaku assertif sebanyak 55,55\% dengan sub indikator menunjukkan sikap berani mengajukan pertanyaan saat pembelajaran online sebanyak $55,55 \%$ dan menunjukkan sikap berani berinteraksi saat pembelajaran online sebanyak 55,55\%. Berikut hasil respon keterampilan sosial siswa pada indikator kemampuan akademis (pernyataan no 2 dan 6) dalam diagram berikut ini:

2. Saya mengajukan pertanyaan saat pembelajaran online (whatsApp/ zoom/ video call).

27 tanggapan

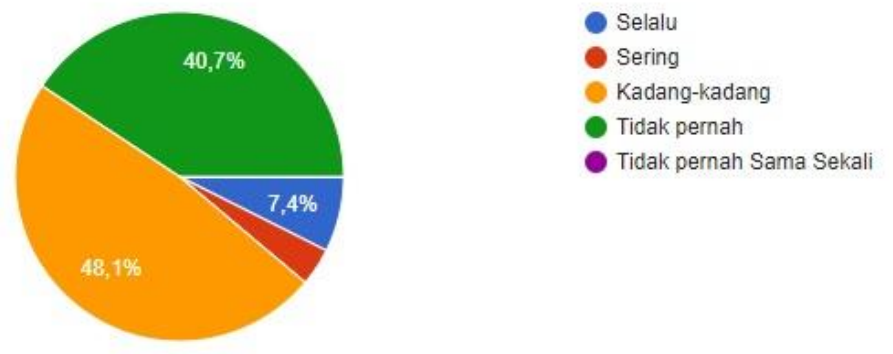

Gambar 9. Hasil respon pernyataan nomor 2 
6. Saya menyapa teman saat pembelajaran tatap muka virtual (zoom meeting/ video call).

27 tanggapan

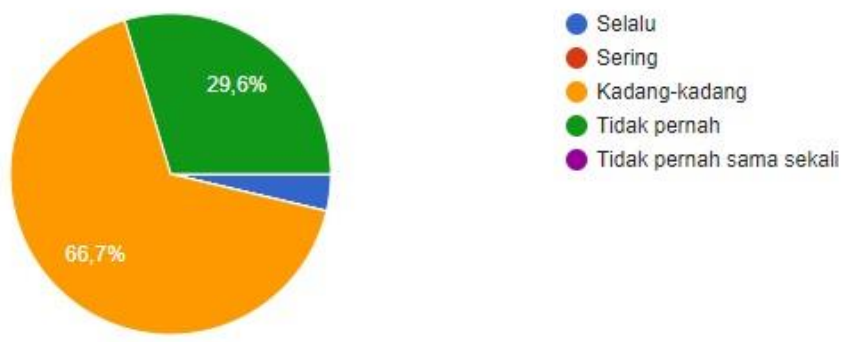

Gambar 10. Hasil respon pernyataan nomor 6

\section{KESIMPULAN}

Dari hasil penelitian dan pembahasan yang dikemukakan bahwa sebanyak 68,96\% siswa memenuhi lima indikator keterampilan sosial siswa saat pembelajaran online. Adapun tiga indikator tersebut yaitu: hubungan dengan teman sebaya, manajemen diri, kemampuan akademis, kepatuhan, perilaku assertif. Hambatan siswa selama proses pembelajaran online yaitu: siswa masih beradaptasi dengan lingkungan belajar saat ini, masalah jaringan internet, peran guru dan orang tua masih kurang maksimal. 


\section{DAFTAR PUSTAKA}

\section{Jurnal:}

Agusta, I. (2003). Teknik Pengumpulan dan Analisis Data Kualitatif. Pusat Penelitian Sosial Ekonomi. Litbang Pertanian, Bogor, 27.

Astini, N. K. S. (2020). Pemanfaatan Teknologi Informasi dalam Pembelajaran Tingkat Sekolah Dasar pada Masa Pandemi Covid-19. Lampuhyang, 11(2), 13-25.

Darmalaksana, W., Hambali, R., Masrur, A., \& Muhlas, M. (2020). Analisis Pembelajaran Online Masa WFH Pandemic Covid-19 sebagai Tantangan Pemimpin Digital Abad 21. Karya Tulis Ilmiah (KTI) Masa Work From Home (WFH) Covid-19 UIN Sunan Gunung Djati Bandung, 1-12.

Ernawati, I. (2017). Uji kelayakan media pembelajaran interaktif pada mata pelajaran administrasi server. Elinvo (Electronics, Informatics, and Vocational Education), 2(2), 204-210.Fitriani, F., Wahjoedi, W., \& Towaf, S. M. (2017, June). Peningkatan keterampilan sosial siswa SD melalui penerapan model make a match berbantuan kartu gambar. In Prosiding Seminar Nasional Mahasiswa Kerjasama Direktorat Jenderal Guru dan Tenaga Kependidikan Kemendikbud 2016.

Faradita, M. N. (2019). Peningkatan Hasil Belajar IPA Di SD Dengan Menggunakan Metode Pq4r. Jurnal Bidang Pendidikan Dasar, 3(1), 7-13.

Herayanti, L., Fuaddunnazmi, M., \& Habibi, H. (2017). Pengembangan Media Pembelajaran Berbasis Moodle pada Mata Kuliah Fisika Dasar. Jurnal Pendidikan Fisika dan Teknologi, 1(3), 205-209.

Mania, S. (2017). Observasi Sebagai Alat Evaluasi dalam Dunia Pendidikan dan Pengajaran. Lentera Pendidikan: Jurnal Ilmu Tarbiyah dan Keguruan, 11(2), 220- 233.

Maryuliana, M., Subroto, I. M. I., \& Haviana, S. F. C. (2016). Sistem informasi angket pengukuran skala kebutuhan materi pembelajaran tambahan sebagai pendukung pengambilan keputusan di sekolah menengah atas menggunakan skala likert. TRANSISTOR Elektro dan Informatika, 1(1), 1-12.

Minarni, A. (2013). Pengaruh pembelajaran berbasis masalah terhadap kemampuan pemahaman matematis dan keterampilan sosial siswa SMP Negeri di Kota Bandung. Jurnal Paradikma, 6(02), 162-174.

Nazir, M. (1988). Metode Penelitian. Jakarta: Ghalia Indonesia.

Purnama, A. (2017). Optimalisasi Keterampilan Sosial ABK Melalui Metode Bermain Kooperatif Pada Paud Inklusi. Prosiding SNasPPM, 1(1), 39-46.

Setiawan, A. R., \& Ilmiyah, S. (2020). Lembar Kegiatan Siswa untuk Pembelajaran Jarak Jauh Berdasarkan Literasi Saintifik pada Topik Penyakit Coronavirus 2019 (COVID-19). EdArXiv. DOI: https://doi. org/10.35542/osf. io/h4632.

Setiawan, F. (2018). Pengaruh Pembelajaran Kooperatif Tipe STAD Terhadap Keterampilan Interpersonal Siswa Kelas IV Sekolah Dasar. JTIEE (Journal Of Teaching In Elementary Education), 1(2), 1-7. doi:10.30587/jtiee.v1i2.267

Suhandani, D., \& Julia, J. (2014). Identifikasi Kompetensi Guru Sebagai Cerminan Profesionalisme Tenaga Pendidik Di Kabupaten Sumedang (Kajian Pada Kompetensi 
Pedagogik). Mimbar Sekolah Dasar, 1(2), 128-141.

Wahidah, R. (2020). Penilaian Sikap Tanggung Jawab pada Pembelajaran Bahasa Arab

Daring Via Whatsapp di Madrasah Tsanawiyah. Prosiding Konferensi Nasional Bahasa Arab, 6(6), 506-519.

Yuliana. (2020, february), Corona Virus diseases, journal vol 2, no 1, p. 187-192. Universitas Lampung diakses melalui

(https://wellness.journalpress.id/wellness/article/view/21026/pdf)

\section{Website:}

Kemdikbud. (2020). SE Mendikbud: Pelaksanaan Kebijakan Pendidikan dalam Masa Darurat Penyebaran Covid-19. https://www.kemdikbud.go.id/main/blog/2020/03/semendikbud- pelaksanaan-kebijakan-pendidikan-dalam-masa-daruratpenyebaran-covid19, diakses tanggal 25 Oktober 2020.

Mukaromah, vina fadhrotul. (2020).

https://www.kompas.com/tren/read/2020/04/01/061500965/who-gunakan-

istilah-physical- distancing-ini-bedanya-dengan-social , diakses tanggal 10 Oktober 2020 